\title{
THE ROLE OF THIRD SECTOR ORGANIZATIONS IN RURAL DEVELOPMENT
}

\section{VÝZNAM ORGANIZÁCIÍ TRETIEHO SEKTORA VO VIDIECKOM} ROZVOJI

\author{
ING. GABRIELA VACEKOVÁ, PH.D. \\ ING. SiMONA ŠKARABELOVÁ, PH.D. \\ Katedra veřejné ekonomie $\mid$ Department of Public Economics \\ Ekonomicko-správni fakulta Faculty of Economics and Administration \\ Masarykova univerzita Masaryk University \\ $\triangle$ Lipová 41a, 60200 Brno, Czech Republic \\ E-mail: gabriela.vacekova@econ.muni.cz,simona@econ.muni.cz
}

\begin{abstract}
Anotácia
Organizácie tretieho sektora reflektujú a vytvárajú komunitné podmienky. Za účelom preukázania ich úlohy a významu vo vidieckom rozvoji prezentujeme teoretický a empirický prístup $k$ rurálnemu tretiemu sektoru. Predkladaný príspevok vychádza z novej ekonomickej teórie tretieho sektora, "teórie rurality". Túto teóriu formuloval Vladislav Valentinov a vychádza z predpokladu, že existencia tretieho sektora je zaprićinená obmedzenou schopnostou ziskových firiem uspokojit' ludské potreby, pričom dôvodom sú špecifické charakteristiky vidieckych oblastí a z nich vyplývajúce "ruralitné špecifické náklady”. Základnou hypotézou teórie rurality je, že ruralitné špecifické náklady podnecujú vznik vidieckych organizácii tretieho sektora. Existujú empirické dôkazy z rôznych krajín (napr. USA a Belgicka), ktoré bud' potvrdzujú alebo vyvracajú význam rozdielov medzi vidiekom a mestom ako determinantu úlohy tretieho sektora $v$ rurálnom rozvoji. V príspevku prezentujeme medzinárodný výskumný projekt "Third sector organizations in rural development: a theoretical and empirical analysis" v podmienkach Českej republiky. Výskumné aktivity predpokladajú prinos významného množstva teoretického a empirického materiálu na testovanie opodstatnenosti teórie rurality.
\end{abstract}

\section{Kl'účové slová}

vidiecky rozvoj, treti sektor, neziskové organizácie, teória rurality

\section{Annotation}

Third sector organizations reflect and shape community conditions. To show their role and importance in rural development we present theoretical and empirical approach to the rural third sector. The paper is based on a new economic theory of the third sector, the "rurality theory". This theory was formulated by Vladislav Valentinov and assumes that the existence of the third sector is caused by the limitations of for-profit firms' ability to satisfy human needs. The argument to their limitations is characteristics of rural areas and the resulting "rurality specific costs". Thus, the rurality theory's general hypothesis is that the rurality-specific transaction cost gives rise to the emergence of rural third sector organizations. There is some empirical evidence from different countries (e.g. USA and Belgium) either confirming or refuting the rural-urban distinction as a determinant of the third sector's role in rural development. The paper presents the survey outline "Third sector organizations in rural development: a theoretical and empirical analysis" on the case of the Czech Republic. The research activities are expected to deliver a critical mass of theoretical and empirical material for testing the rurality theory.

\section{Key words}

rural development, third sector, non-profit organizations, rurality theory 
JEL classification: $L 31$, R19

\section{Introduction}

Scope of third sector organizations is so diverse that it is impossible to find a single term to define them. Therefore many authors (Anheier and Salomon, 1999; Bútora, 2011, Frič, Goulli, 2001, Haken, 2005, Hansmann, 1996; Hyánek, 2011; Ondrušek, 1998; Pestoff, 2006; Petijová, Woleková, 2006; Rektořík, 2001, Rose-Ackerman, 1996; Toepler, 2003, Weisbrod, 1988, etc.) in a number of publications prefer a broader description of the characteristics of non-profit organizations. The structural-operational definition by Anheier and Salamon (1999) can be used. According to this definition an NGO should comply five characteristics: institutionalization, independence, nondistribution constraint, self-government, voluntary participation.

In many parts of the world, rural development is supported by third sector organizations, such as NGOs, farmer associations, self-help groups, rural partnerships and cooperatives. Although the contribution of these organizations to rural development has been widely recognized empirically (e.g., OECD 2006), the theoretical understanding of their economic rationale has remained unsatisfactory (Valentinov, 2012).

There are some specific rural NPOs characteristics (compared to urban counterparts), such as (Curtisss, 2012):

- mainly traditional NPOs (volunteer firemen groups, hobby clubs);

- nontraditional NPOs (community building, service, expressive) frequently organized by newcomers (drift) to rural areas with urban experience;

- more closely watched due to strong social ties;

- smaller size, large scope of activities limited to activities manageable with voluntary labor;

- primary financial and material support from local government (small! grants, importance of material support), complain about clientelism in connection to state funding;

- professionalization mainly by rural residents with urban experience (studies or employment in a city) or weekend residents.

The respective gap in the literature is reflected in the major economic theories of the third sector having been developed with no regard to the rural context (see Steinberg 2006 for an overview). Indeed, neither of these theories, including the public goods theory, trustworthiness theory, consumer control theory, ideological entrepreneurship theory, can appropriately account for the specificity of rural conditions in explaining the existence of the rural third sector (Valentinov, 2012).

\section{Research methodology}

Formulating the rurality theory of the third sector will be done in three thematic areas (Valentinov, 2012):

- analyzing the effect of rurality on the institutional choice in rural areas;

- testing the alternative economic theories of the third sector in rural areas;

- rationalizing rural-urban differences in the structure and behavior of third sector organizations.

Empirical testing will be based on econometric methods and case studies.

The data for conducting the empirical part of the research will be collected in Germany, Czech Republic, and Ukraine. The research is conducted by IAMO (Leibniz Institute of Agricultural Development in Central and Eastern Europe) from Halle, Germany. The partner in the Czech Republic is CVNS (Centrum pro výskum neziskového sektoru) at the Department of Public Economics, Masaryk University in Brno. 
Selection of rural areas in the Czech Republic utilized the typology of rural areas by Perlin et al. (2010) and focused on two types of rural areas: "nerozvojovy sousedsky venkov" and "vybaveny moravsky venkov". Criteria for selection were as follows (Curtiss, 2012):

- Municipalities in the size of 200-1500 residents;

- Share of agricultural land $>=40 \%$

- Distance to the border at least $20 \mathrm{~km}$.

The questionnaire survey in the Czech Republic will be conducted in 250 municipalities from Jihomoravský kraj and Vysočina (partly also Zlínský and Olomoucký kraj). The survey data will be complemented with municipal statistical data. After the municipality level survey there will be a NPO level survey. While the municipality level survey is aimed at understanding the scope, structure and role of NPOs in rural governance and public good delivery, the NPO level survey will result in understanding the incentives for establishment and conditions of effective operation of rural NPOs (when compared to urban NPOs). To do that in appropriate way a control sample of urban respondents will be needed.

The major innovation of the research lies in the proposition of a new economic theory of the third sector and in substantiation of the rural-urban distinction as a determinant of the theoretical rationale of the third sector. Related to this innovation there are two sources of risk justifying the five-year duration of the research (Valentinov, 2012):

- 'liability of newness' of the rurality theory of the third sector;

- relative deficit of official statistics on third sector organizations.

The first source of risk would be addressed by accumulating a critical mass of research findings and by active communication of these findings to the research community. The second source of risk would be addressed by active networking with national and international third sector organizations themselves in order to get access to the data and to disseminate research findings.

The research intends to create a new field of economic research located at the intersection of the economic theory of the third sector and agricultural economics, thus extending the boundary of the economic discipline 'from within' (Valentinov, 2012).

\section{State of the art}

In line with the overall trend of growing political relevance of the third sector in the modern world (Salamon and Anheier 2006), the rural third sector enjoy increasing political recognition as well (Valentinov, 2012). In the developed countries, the role of rural third sector organizations has been enhanced by the shift 'from government to governance' involving the transfer of responsibilities from the state to the private for-profit and third sectors (Goodwin 1998; Valentinov and Fritzsch 2009 forthcoming; Valentinov and Baum 2008). Accordingly, the recent trend in the rural development policy in Europe has been toward increasing reliance on partnerships beyond the formal structures of government, as has been articulated in the Cork Declaration and a number of other European rural policy documents (Goodwin 1998). These partnerships, which bring together stakeholders of all three societal sectors - market, state, third sector - themselves clearly represent third sector organizations. In the developing countries, the importance of the rural third sector has been appreciated primarily as a result of relatively low effectiveness of both state-led and market-led policies of agricultural and rural development (Kydd and Dorward 2004; Valentinov 2008a).

\subsection{Rurality theory}

The author of the new third sector theory Rurality theory is Vladislav Valentinov. Based on his assumptions, the recognized empirical relevance and the growing political popularity of the rural third sector have not so far been matched by the corresponding development of the economic theory of the rural third sector (Valentinov, 2012). Indeed, this theory has been missing at all. The traditional general theories of the third sector emphasized its role in the provision of public goods (Weisbrod 
1991), gaining consumers' trust (Hansmann 1987), ensuring better consumer control over production of goods and services (Ben-Ner 1986), and serving as an outlet for ideological entrepreneurship (Rose-Ackerman 1996). These theories have clearly been developed with no regard to the distinction between rural and urban regions. Hence, neither theory is adequately positioned to take account of the specificity of rural conditions in explaining the existence of the rural third sector.

The case for developing the economic theory of the rural third sector is not self-evident. It can be met with the objection that rural third sector organizations, just like their urban counterparts, can be satisfactorily explained in terms of the standard economic theories. However, there are two interrelated arguments that justify the need for the rural third sector to be explained by an extra theory different from the traditional ones (Valentinov, 2012). First, the traditional general economic theories of the third sector agree that the third sector is generally caused by the limitations of the ability of forprofit firms to satisfy human needs (Steinberg 2006; Hansmann 1987). Second, the literature on international rural development strongly suggests that rural areas, in both developed and developing countries, have a number of socio-economic characteristics that result in high transaction cost constraining the operation of for-profit firms (Terluin 2001; Baum and Weingarten 2005).

Thus there are grounds to argue that spatial and socio-economic characteristics of rural areas create a niche for rural third sector organizations and hence constitute a distinct theoretical reason for their existence (Valentinov 2009a forthcoming). In the following, the argument that socio-economic characteristics of rural areas create a niche for rural third sector organizations will be referred to as the 'rurality' theory of the third sector. The rurality theory of the third sector presents a logical continuation of the applicant's previous work on the sector-specific organizational economics rationale of agricultural cooperatives (Valentinov 2007a) and the self-sufficiency theory of the third sector (Valentinov 2008b).

\subsection{Rurality transaction costs}

The indicated characteristics of rural areas, while broad and stylized, follow from spatial and territorial approaches to understanding rurality (Terluin 2001; Saraceno 1994; Cloke 1985). Accordingly, in conducting empirical research, these characteristics may be supplemented with other characteristics that are put forward by these approaches and that may be indirectly indicative of the rurality-specific transaction cost - e.g., unemployment rate, employment share of agriculture, share of built-up area, per-capita incomes, demographic structure (Valentinov, 2012).

While the traditional transaction cost theory of new institutional economics explains the existence of the for-profit firm in terms of its transaction cost-economizing role (Coase 1937; Williamson 1996), the rurality-specific transaction cost stems from those rural areas' characteristics that cannot be altered by for-profit firms. Hence, the rurality-specific transaction cost is most appropriately analyzed not from the perspective of the traditional transaction cost theory, but rather from the perspective of the theory of the social division of labor (Valentinov 2006a). The latter theory argues that transaction cost may act as a constraint on the social division of labor and thus give rise to partially replacing of market exchange with self-sufficiency. In yet another contribution, the applicant proposed that third sector organizations must be generally viewed as institutional embodiments of partial collective selfsufficiency in situations where market exchange, mediated by for-profit firms, is not possible (Valentinov 2008b).

Various economic theories of the third sector have thereby been shown to refer to specific instances of transaction cost acting as a constraint on the division of labor (ibid). Accordingly, the proposed rurality theory of the third sector is concerned with the rurality-specific transaction cost. Thus, the applicant's previous work involved developing an integrative meta-theoretical framework that not only reconciles the traditional theories (Valentinov 2009), but also integrates the proposed rurality theory into the logical structure of the extant theoretical literature on third sector economics. 


\subsection{Preliminary empirical findings}

The empirical relevance and the growing political popularity of the rural third sector have been already empirically recognized. We can demonstrate two different findings on two different research outcomes concerning the rural development.

The first one uses data on Internal Revenue Service-registered nonprofits for Indiana counties. The authors (Kirsten A. Gronbjerg, Laurie Paarlberg, 2001) from Indiana University (USA) examined how theories of demand, supply and social structure predict the overall density of nonprofits in local communities. The authors found substantial county-level variations in the densities of nonprofits overall and of charitable, advocacy, and mutual-benefit nonprofits. Using multiple regression techniques, they were able to explain $20 \%$ to $46 \%$ of overall variation (depending on legal category involved) in nonprofit densities. Their findings support the supply and social structure but not demand, explanations and reveal somewhat divergent patterns for the various types of nonprofits.

The second one was conducted in Belgium (Marc Hooghe, Sarah Botterman, 2009). Their goal was to assess the impact of urbanization on participation in voluntary associations. The analyses, however, did not support these alleged negative effects of urban life. Population density, city size, or belonging to a metropolitan area did not have a significant impact on the intensity or the scope of participation in voluntary associations. Their results therefore do not support the hypothesis of a rural-urban divide in participation in voluntary associations.

To find out the situation in our conditions we will conduct the research "Third sector organizations in rural development: a theoretical and empirical analysis" on the case of the Czech Republic. There was CVNS representative survey conducted by Zuzana Prouzová from Masaryk University in Brno in 2012, which was aimed at the relationship between municipalities and NGOs, at the forms and reasons for supporting NGOs from municipalities. But a similar research that would deal with the role of third sector organizations in the Czech rural development has not been published yet.

\section{Survey outline}

The research is aimed at filling a research gap by formulating and empirically testing a new economic theory of the third sector, the rurality theory. The objective of the proposed research project is twofold (Valentinov, 2012):

- to formulate empirically testable hypotheses following from the rurality theory of the third sector;

- to empirically test these hypotheses, particularly in contrast with hypotheses following from the traditional general theories of the third sector.

It is planned to investigate the research objective on example of three countries, Germany, Czech Republic, and Ukraine. The choice of these countries is motivated by three reasons, such as (Valentinov, 2012):

- the opportunity to identify the effects of socialist transition (as a characteristic of institutional environment) on the development of the rural third sector, as these countries exhibit varying states of advancement of over the socialist past;

- the availability of reliable research partners in these countries;

- and the expectation of more extensive empirical results required for better empirical justification of the theoretical framework.

Since the thematic areas will be pursued in three different countries, it is planned to develop an integrated data collection procedure that will ensure cost-effectiveness of data collection and comparability of data. 


\subsection{Research areas}

Based on the proposed approach, the thematic areas within which the rurality theory of the third sector will be developed and empirically tested include (Valentinov, 2012):

1. Analyzing the effect of rurality on the institutional choice in rural areas. Institutional choice will thereby be broadly understood as the choice between market, state, and the third sector. The overall hypothesis following from the rurality theory is that the rurality-specific transaction cost (as well potentially other rurality-specific characteristics) will be one of determinants of occurrence of the third sector in rural areas. This thematic area is innovative because the major economic theories of the third sector have been so far more focused on revealing this sector's unique economic role than on developing models of inter-sectoral institutional choice. At the same time, analyzing institutional choice has been a major theme in the new institutional economics literature on the for-profit sector (e.g., Williamson 1996). Yet, this literature's implications for understanding the choice between the three societal sectors in the development of rural areas remain largely unexplored. This thematic area will aim at closing this research gap.

2. Testing the alternative economic theories of the third sector in rural areas. This thematic area will be the central part of the proposed project. Empirical testing of competing theories has been an important theme in the current third sector research literature (e.g. Salamon and Anheier 1998), yet it has so far had little relevance to the rural third sector. Moreover, as mentioned above, the rurality theory has not been tested along with the traditional theories. The proposed project will fill this gap in the literature.

3. Rationalizing rural-urban differences in the structure and behavior of third sector organizations. The rurality theory hypothesizes in this respect that structural and behavioral characteristics of rural third sector organizations (and particularly of those organizations explained by the rurality theory) will systematically differ from the respective characteristics of urban third sector organizations. This thematic area is innovative since the traditional economic theories of the third sector do not examine whether the general reasons for the emergence of the third sector are variously represented in rural and urban areas.

\subsection{Expected results}

It is expected to make theoretically and empirically grounded statements about (Valentinov, 2012):

- the determinants of institutional choice between market, state, and the third sector and rural areas;

- the relative validity of the rurality theory and other theories of the third sector in rural areas;

- the major variations in the structure and behavior of third sector organizations in urban and rural areas.

The statements will be formulated for the Czech Rebulic and afterwards compared with conditions of other involved countries. In the broader point of view the research is also aimed at generating recommendations for public policy towards the third sector (Valentinov, 2012).

The realization of the research should help establishing the rurality theory of the third sector in the multidisciplinary literature on the third sector. The research activities are expected to deliver a critical mass of theoretical and empirical material for this purpose (Valentinov, 2012). Ideally, the rurality theory would occupy the same status as the traditional theories of the third sector, at least in the literature on the rural third sector.

\section{Conclusion}

In line with the traditional economic theories of the third sector, the rurality theory assumes that the existence of the third sector is caused by the limitations of for-profit firms' ability to satisfy human 
needs. The original contribution of the rurality theory is in the argument that some of the limitations of for-profit firms located in rural areas are related to characteristics of rurality, such as low population density, geographical dispersion, and poor infrastructure. These characteristics give rise to 'ruralityspecific' transaction cost that must be borne by for-profit firms located in rural areas. The ruralityspecific transaction cost constrains the scope of operation of rural for-profit firms, thus diminishing their ability to satisfy rural dwellers' wants and creating a niche for rural third sector organizations (Valentinov, 2012).

The aim of the paper was to present theoretical and empirical basis explaining the role of the third sector organizations in the rural development. We described the research sample and the data collection process within an international project "Third sector organizations in rural development: a theoretical and empirical analysis" on the case of the Czech Republic. The major innovation of this research project lies in the proposition of a new economic theory (rurality theory) of the third sector and in substantiation of the rural-urban distinction as a determinant of the theoretical rationale of the third sector. The fulfillment of the project objectives will be realized by analyzing the logical relationship between the concepts of rurality and the third sector.

The presented paper opens the discussion by formulating and empirically testing a new economic theory of the third sector, the rurality theory. We also try to point out where future research is needed.

\section{Literature}

[1] COASE, R.. The nature of the firm. Economica, 1937, 4. p. 386-405.

[2] CURTISS, J. Rural-Urban Divide in Funding and Accountability of NPOs A Regional Case Study in the Czech Republic. In 10th ISTR International Conferences, Siena, 10-13 July 2012.

[3] GRØNBJERG, K. A.- PAARLBERG, L. Community variations in the size and scope of the nonprofit sector: Theory and preliminary findings. Nonprofit and Voluntary Sector Quarterly, 2001, 30(4), p. 684-706.

[4] HANSMANN, H. Economic theories of nonprofit organization.In: Powell, W. (ed.). The Nonprofit Sector:A Research Handbook. New Haven et al.: Yale University Press, 1987. p. 2742.

[5] HOOGHE, M., BOtTeRMAN, S. Urbanization, Community Size, and Population Density: Is There a Rural-Urban Divide in Participation in Voluntary Organizations or Social Network Formation? Nonprofit and Voluntary Sector Quarterly, 2012, 41(1) p. 120-144. DOI: 10.1177/0899764011398297.

[6] HYÁNEK, V. Neziskové organizace: teorie a mýty. Brno: Masarykova univerzita, 2011. 132 p. ISBN 978-80-210-5651-0.

[7] OECD. Das neue Paradigma für den ländlichen Raum: Politik und Governance (in German). Paris: OECD Publications, 2006. 184 p.

[8] PROUZOVÁ, Z. Obce ČR a NNO. 2012. Dostupné z: <http://cvns.econ.muni.cz/projekty/53>.

[9] ROSE-ACKERMANN, S. Altruism, nonprofits, and economic theory. Journal of Economic Literature, 1996, 34: 701-728.

[10] STEINBERG, R. Economic theories of nonprofit organization. In Powell, W. and Steinberg, R. (eds.) The NonprofitSector: A Research Handbook, 2nd Ed. New Haven et al.: Yale University Press, 2006. p. 117-139.

[11] VALENTINOV, V. (2009a). Third sector organizations in rural development: a transaction cost perspective. Agricultural and Food Science, 2009, 18(1), 3-15.

[12] VALENTINOV, V. (2009b). Mapping the third sector in John R. Commons' typology of transactions. Journal of Economic Issues, 2009, 43(4), 917-930. DOI: 10.2753/JEI00213624430405.

[13] VALENTINOV, V. The meaning of nonprofit organization: insights from classical institutionalism. Journal of Economic Issues, 2011, 45(4), 901-916.

[14] VALENTINOV, V. Understanding the rural third sector: insights from Veblen and Bogdanov. Kybernetes, 2012, 41(1/2), 177-188. 
[15]VALENTINOV, V., \& LARSEN, K. The meaning of non-profit mission breadth: A constitutional economics perspective. The Social Science Journal, 2011, 48(1), 29-38.

[16] WEISBROD, B. A. The nonprofit economy. Harvard University Press, 1988.

[17] YOUNG, D. R. Alternative models of government-nonprofit sector relations: Theoretical and international perspectives. Nonprofit and Voluntary Sector Quarterly, 1999, 29(1), 149-172.

[18] WILLIAMSON, O. The mechanisms of governance. Oxford: Oxford University Press, 1996. 429 p.

This article has been elaborated as one of the findings of research project CZ.1.07/2.3.00/30.0009 Employment of Newly Graduated Doctors of Science for Scientific Excellence. 